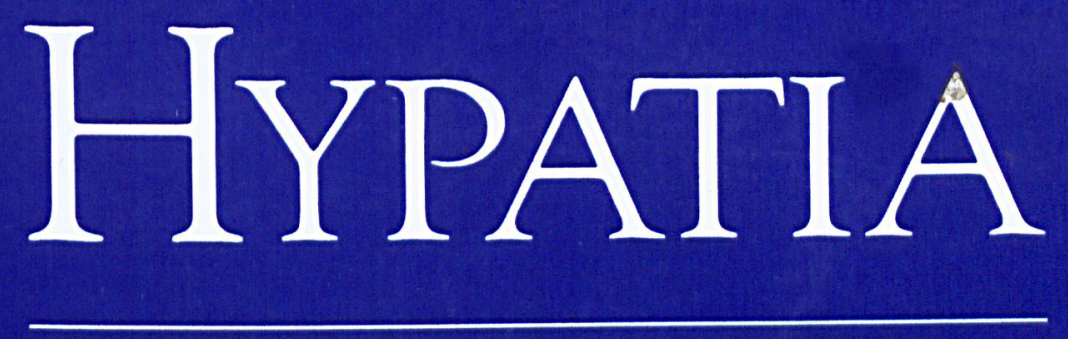

\title{
SPECIAL ISSUE
}

French Feminist Philosophy

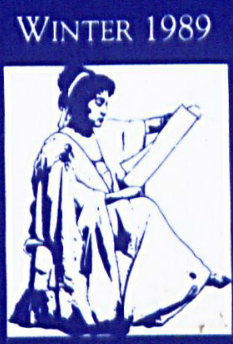

A Journal of Feminist Philosophy 